\title{
Students' Ability and Difficulties in Understanding English Text (A Study at English Program IAIN Padangsidimpuan)
}

\author{
Eka Sustri Harida \\ English Department, Faculty of Islamic Education and Teacher Training \\ IAIN Padangsidimpuan, Indonesia \\ E-mail: esha stainpasid@yahoo.com \\ DOI: http://dx.doi.org/10.15548/jt.v21i3.102
}

\begin{abstract}
This study deals with the ability of the students to understand English texts and types of their reading strategies. It is believed that reading strategies help students improve their reading comperehension. Based on this theory, then, the qualitative research was carried out to describe students' reading ability and types of strategy they used. Data were collected through questionnaires that have been distributed to 34 students. They were also observed and tested. It was found that the students' ability in understanding text was still low. They had many problems in understanding English texts because they did not apply appropriate reading strategies in their reading activities. Their low reading comprehension was due to their lack of reading strategies.
\end{abstract}

Keywords: Student's ability, reading strategies, student's reading problems, and reading comprehension.

\section{INTRODUCTION}

Reading is one way to develop the human's capability to perceive the world around them. Since many sources of knowledge are now written in English, there is a high time for the university students to develop their reading skills through some learning strategies. Besides, reading is the first thing that God asked human to do as shown in the first surah (Al-'Alaq):

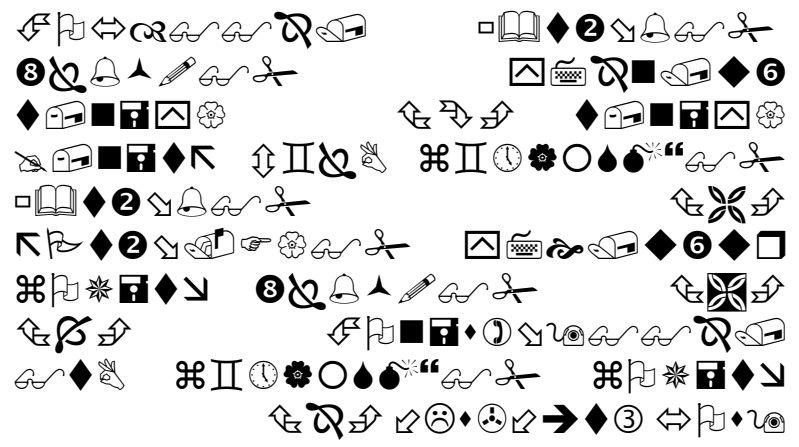

The Almighty God (Allah) asked human to learn by reading and it is supported by Surah AlMujaadilah 11 that states God will raise the people who have knowledge.

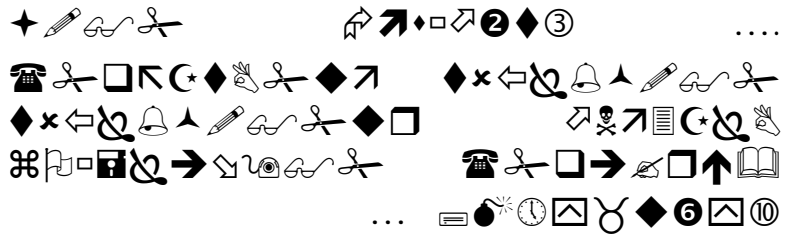

Although these Quranic verses have long emerged in the teachers and students' minds, the ultimate advantages of reading are unlikely achieved by the readers as they suffered from the inability to comprehend the English texts. It is argued that, based on evidences, students are lack of strategies for reading.

\section{Reading Comprehension}

The primary aim of reading is to take ideas from what hase been read, and interpret the meanings based on readers' background knowledge. Nadrah (2004) as cited in Young ()said that:

Comprehension focuses on reading instruction, such as: (1) understanding words and building vocabulary, (2) understanding 
sentences, sentence structure, and syntax, and (3) understanding paragraph, which include finding the main idea and topic sentences, finding detail, and drawing conclusion and interpretation what you read. Further, in comprehension at least needs three skills which should be possessed as a reader; knowledge of words forms and their meanings, the ability to understand the sentence in a paragraph, the ability to see the main thought of the writer and get the general ideas of a piece of reading material.

Reading comprehension is a process of understanding the text, namely to take the ideas, the information, and then interpret the meaning. It is a mental process in which the readers try to understand the meaning in the text by interpreting what have been read in order to find the idea given by the writers (Eka, 2012). In reading comprehension, the readers should pay attention to some aspects such as the words and the information, try to understand the main ideas and details, and be able to make conclusion.

Reading is one of the English skills that should be mastered by the students in learning English. It is one of receptive skills which is very significant nowadays. It is not just a visual activity, nor a simple matter of decoding to sound. Smith (1978) emphasizes on two sources of information that are essential for reading, visual information and non-visual information. These sources are very helpful for the students to comprehend a text in reading.

There are so many reading strategies; as top-down and bottom-up strategies, memory, cognitive, compensatory, meta-cognitive, affective and social strategies, identify the purpose of reading, use grapheme rules and patterns to aid in bottom-up decoding, use efficient silent reading techniques for relativity rapid comprehension, skimming, scanning, semantic mapping, guessing, vocabulary analysis,distinguish between literal and implied meanings, and capitalize on discourse markers to process relationship (Carrel, 1988; Oxford, 1990; and Brown, 2001). Reading strategies have many functions; as increasing students' ability in reading, improve students' interest and motivation, and others. By using various reading strategies in reading English texts, it is hopefully can enrich students' reading comprehension.

There are also many reading strategies based on Adler that can improve students' reading comprehension; they are monitoring comprehension metacognition, graphic and semantic organizer, answering questions, generating questions, recognizing story structure, and summarizing. Moreover, in applying reding strategies, the readers or the students must pay attention to the inapproprite strategies used. A great deal of research in first language reading over the last 25 years has shown that unskilled readers do not use strategies often or effectively without help (Carrell, 1988). She also states that failure to use reading strategies effectively occurred to unskilled readers when (a) they fail to monitor their comprehension, (b) they believe that the strategies will not make a difference in their reading, (c) they lack of knowledge about texts features, (d) they are disinterested in text and unwilling to use strategies, and (e) they prefer familiar yet primitive strategies over less familiar but more effective tactics (Carrel, 1988). To overcome the failures of the students in using reading strategies effectively, it needs helping from the other one, such as teachers.

The other ideas about reading comprehension are based on process and level of comprehension. Based on process comes from Clark and Clark (1977) who states that there are two processes of comprehension; construction process in which the way listeners construct an interpretation of the sentence from the speakers' words, and utilization process which concerned with how the listeners utilize the interpretation for further purpose for registering new information, answering questions, following orders, registering promises, and the like. 
This research is related to Chauliyah (2010) and Nurhanifah (2010) who found that the students had problems in understanding text; had less motivation and interest, and they didn't have good reading strategies. They didn't have appropriate reading habit. Students were idetified to have lacked of vocabularies and practice. In fact, the students are still unable to practice reading strategies although they have had enough ability in reading comprehension.

\section{METHOD}

This research aimed at describing students' ability in reading comprehension, their problems in reading comprehension, and types of their reading strategies. The data were taken from the fifth semester of English Education Study Program (34 persons) who registered 2011/2012 Academic Year.

Data were collected through observation, interview, reading test, and questionnaires. Observation was used to describe the students' learning process during the reading process. Interviews were carried out to find out their problems in understanding English texts. Then, reading test was administered to describe students' reading comprehension. Questionnaires were used to take the data about their reading strategies. Finally, data were analyzed through some steps: verifying, scoring, grouping, and interpreting.

\section{RESEARCH FINDINGS}

\section{Students' Reading Problems}

Students' ability in understanding English text is influenced by many factors; such as vocabulary, reading habit, interest, schemata, pronunciation, and other. It is known from the interview that most students had problem in vocabularies. When they were asked to answer or to solve the problems they usually failed to do so because of their limitation in vocabularies. It is known that vocabulary is a core to understand every languages in the world; having less vocabulary will impact to their less ability in communication.

Another problem encountered by the students was in activating background knowledge or schemata while reading. This strategy actually help students to understand the text by connecting what they have read to their knowledge. The other problem is their inability to connect whet they read to the context. In connecting their knowledge to the context, the students also needs to guess the meaning of unknown words.

Students who got low score in reading comprehension admitted they got difficulties to find main ideas and supportings paragraph. They also got difficulties in applying reading strategies in their reading activites. As stated by Adler that reading strategies are tools for students to understand English. If the students are able to apply reading strategies, the comprehension about English text should not be difficult anymore. Besides, the students' problems in understanding text are their inability to set the purpose, aims, and time in reading. They had low motivation and interest as stated before.

Students' lack of practice and having limited knowledge of genre contribute to their weaknesses in reading. They seemed to dislike the text; they seldom opened their dictionaries. Frequently, they asked their friends beside to help them get the ideas. When they enjoy reading the text, it will make them relax and will help them learn and read seriously. These problems were the hindrances for the students to read and comprehend English texts better; thus, it is needed to be solved by teaching them how to apply reading strategies while motivating them to have good mood.

\section{Students' Reading Strategies}

Students always do three stages in reading such as; pre-reading, while-reading, and postreading. While reading the students have applied various reading stretegis, as skimming, scanning, activating background knowledge (some students), read the contents list, read the topic or sub topic, survey, and also connecting to the 
contexts. The strategies that are rarely used by the students are making questions, predicting the text, and cross-check the text with other information. Making inferences and evaluating their readings are also less practiced by the students.

Based on the observation, it was evidenced that the students were unable to apply reading strategies. When they were asked to find main ideas, they read the whole the texts. Actually they can find the information just by looking at the first sentence in the paragraph or the last. When they were asked to find concluding sentence, they would read it from the first sentence in the paragraph. These are the reasons that made the students unable to comprehend English texts well, because they less practiced reading strategies. As stated before that reading strategies help the readers to understand English text well, increases motivation and interest.

Whereas, there are some advantages of using reading stratgeies in reading activities. They improve the ability of comprehending the text, get ideas quickly, increase attention and concentration, improve motivation and interest in reading, and make reading more active. (Learning Data Base). It is also related to what Mc.Whorter said that reading strategies can increase students' concentration, and become more active readers (Mc. Whorter, 1992).

Based on these reasons, the students should use reading strategies. The findings are in line with Eka (2011), where the third year of English Department students at Muhammadiyah University had applied good and effective reading strategies only some students who used appropriate and various reading strategies got better in comprehending the texts, while the others were not. It is not significant with what had been stated by Grabe and Stoller in which the students with many reading strategies and appropriate reading strategies will be better in reading comprehension. Because what they had been stated did not relate to what the researcher found, in which the students with many reading strategies cannot comprehend the English text well. It might be caused by their application in their reading still not maximum.

\section{Students' Reading Comprehension}

The students had low reading ability because of their problems in understanding it. Their problems have been identified as follows: lack of reading strategies, less motivation and interest in reading. The students did not set purpose; As a result of the research, the students' reading comprehension is various. The accumulation of the result can be seen in the table below:

Table 1

Accomulation of Students' Reading
Comprehension Score

\begin{tabular}{r|r|r}
\hline Score & Frequency & Percentage \\
\hline $30-39$ & 3 & $9 \%$ \\
\hline $40-49$ & 9 & $26 \%$ \\
\hline $50-59$ & 13 & $38 \%$ \\
\hline $60-69$ & 6 & $18 \%$ \\
\hline $70-79$ & 2 & $6 \%$ \\
\hline $80-89$ & 1 & $3 \%$ \\
\hline Accounts & 34 & $100 \%$ \\
\hline
\end{tabular}

Students' reading comprehension is still not enough to be proud yet; because there are still several students (9) who get the score more than 60. It needs hard job for the lecturers to help students to understand the English text. The lecturers should pay attention to the techniques or the way to improve it; althought it is for the informants directly because they have been in the higher level today. It can be done to the next; because the writer thinks that the students' problems are rather same.

What have been found before, is also related to what have been found in the findings that has been stated in Tazkir (2011) that the category of the students' reading comprehension after analyzing the data was enough. It is known from the achievement degree of the students' score in reading comprehension $(48.50 \%)$, it is in the level of enough $(41-60 \%)$. It means the 
students' reading comprehension is still low, and it is needed to be increased to make them better in learning English.

Moreover, the third year of English Program actually had applied good and effective reading strategies. But from the result of the students' reading comprehension exercises that were investigated, only some students who used appropriate and various reading strategies got better in comprehending the texts, while the others were not. Actually, the students who have applied various readig strategies, also have good result in reading comprehension well; but others cannt; it might be caused of their application in their reading still not maximal yet. For the students who still cannot apply reading strategies, exactly they donot have good abilities in reading comprehension. The big problems of the students' inability to comprehend English text are vocabulary and reading strategies; the students do not have enough vocabularies and cannot apply reading strategies. Thus, it is needed to be solved, the students should teach more about how to aplly reading strategies and asked to improve their vocabularies. It can be done by practicing more in reading comprehension.

\section{CONCLUSION}

From the findings, it is known that the students' reading comprehension are still low, it is seen from the score (mean 52/82). It is still found that many students are still unble to apply various reading strategies and also many of them have problems in reaing. They didnot know the purpose of reading. They didnot have motivation, concentration, and interest in reading, and others. Thus, it is important for the lecturers to train them with other rellevant strategies.

Based on the findings, it is recommended that:

1. English teachers or lecturers must teach the students about reading strategies and make them aware of choosing appropriate reading strategies in reading English text, and then they approve their students to use various reading strategies in order to support them to study and improve their learning especially reading results.

2. Teachers or lecturers should motivate students hardly in order to make the students have good motivation and interesting in reading.

3. The readers should give enough facilities and also more reading materials, so the students can enjoy reading and also can get many sources about reading materials.

4. Students must apply various reading strategies in their reading activities to comprehend the English text, and expected to be able to choose appropriate reading strategies; so it could assist in comprehending the text.

5. Students shoul practice reading; they should make reading as their daily practice activities to make them be able in reading comprehension well.

6. For other researchers, it can be as inspiration to do more study about English reading strategies and what relate to this finding, and also to continue this research with the others best instruments that can trace the deeper data that were needed.

\section{REFERENCES}

Adler, C. R. (2013). Seven Strategies to Reach Students' Text Comprehension.http:www.adlit.org/arti cle/3479. Retrived on April 15 2013.

Ann, L. (2013). Learning Disability in Reading Comprehension. Error! Hyperlink reference not valid. Retrived on April $15^{\text {th }} 2013$.

Hornby, H.S. (1974). Oxford Advanced Learners' Dictionary of Current English. Great Britain: Oxford University Press.

Brown, D. H. (2001). Teaching by Principles: An Interactive Approach to Language Pedagogy (New York: Addison Wesley Longman, Inc. 
Carrell, P. L, et. al. (1988). Interactive Approaches to Second Language Reading. New York: Cambridge University Press.

Clark, H. H \& Eve V Clark.(1977). Psychology and Language: An Introduction to Psycholinguistics. New York: Harcourt Brace Jovanovich International Edition.

Nurhanifah, D. (2010). The Problems of Second Grade Students of SMP N 4 Malang in Learning English and the Efforts Made to Overcome Them (Laporan Penelitian).

Huraida, E.S. (2011). Reading Strategies Used by English Departement Stduents at Muhammadiyah University. Tazkir Vol. 06 No. 1 Juni 2011 (134-152).

Huraida, E.S. (2012). The Correlation between Vocabulary Mastery and Reading Strategies to Students' Reading Comprehension at the Second Year of English Education Section (TBI) STAIN Padangsidimpuan. Tazkir, Vol. 02 Tahun 2012. Padangsidimpuan.

Shahab, H. (2013). Latar Belakang Kesulitan Membaca Buku Teks Berbahasa Inggris bagi Mahasiswa Bukan Jurusan Bahasa Inggris. Diakses dari http://www.angelfire.com/journal/fsuli melight/ baca.html.pada hari Senin, tanggal 8 April 2013 jam 10:00 WIB.

Klingner, J. K. (2007). Teaching Reading Comprehension to Students with Learning Difficulties (What Works for Special-Needs Learners). New York: A Divison of Guildford Publications.

Learning Strategies Data Base.Guided Reading. Error! Hyperlink reference not valid.. Retrived on March $2^{\text {nd }} 2013$.

Chauliyah, L. (2010). Peningkatan Kemampuan Membaca Pemahaman melalui Word
Identification Skills (Studi Tindakan Kelas terhadap Kesulitan dalam Mengidentifikasi). (Research Report, Ciamis).

Mc.Whorter, K. T. (1992). Efficient and Flexible Reading $3^{\text {rd }}$ edition New York: Harper Collins Publishers.

Nadrah. (2004). The Contribution of Reading Strategies and Vocabulary Mastery to Reading Comprehension. Unpublished Theses. Padang: UNP. 